\title{
The U.S. Economic Downturn And The Euro-Dollar Exchange Rates
}

\author{
Hamid Shahrestani, Ohio University-Chillicothe, USA \\ Nahid Kalbasi Anaraki, Islamic Azad University, Iran \\ Farhad Ghaffari, Islamic Azad University, Iran
}

\begin{abstract}
In this article, we test the forecasting performance of empirical exchange rate models to assess inand out-of-sample fits. The recent U.S. economic downturn has induced the Federal Reserve to decrease the federal fund rate (FFR) regularly, which has further weakened the dollar against major currencies, particularly the euro. To overcome the economic recession, the European Central Bank has also followed this trend by lowering the Euribor. Therefore, the parity power of these two currencies is basically affected by the reaction of European Central Bank against the Federal Reserve. By using the generalized method of moments (GMM), we attempt to predict the behavior of the euro-dollar exchange rates according to various empirical models. Based on different criteria which includes the root mean squared error (RMSE), the mean absolute error $(M A E)$, the Theil coefficient, and variance proportion, our results suggest that the interest rate parity model can predict the euro-dollar exchange rate more accurately than other structural models including a random walk, which alters the results of Meese and Rogoff's work.
\end{abstract}

Keywords: portfolio balance model, sticky price monetary model, interest rate parity condition, random walk, Balassa-Samuelson model, generalized method of moments (GMM

\section{INTRODUCTION}

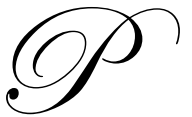

revious assessments of the forecasting power of exchange rate models have focused on a narrow set of paradigms which date back to the 1970s. The seminal paper on this subject was written by Meese and Rogoff (1983), who examined monetary and portfolio balance models against a random walk. In this paper, we reassess the out-of-sample predictability power of the euro-dollar conversion rates by using a wider set of models than has been proposed in existing literature. The performance of in- and out-of-sample predictability of these models are compared against each other by using the root mean squared error (RMSE) and mean absolute error (MAE) criteria. Rather than estimating the cointegrating vector over the entire sample and treating it as part of the ex ante information set, as is generally done in the literature, we implement the generalized method of moments (GMM) to examine the predictability power of different models at various forecast horizons. Our results suggest that the interest rate parity model outperforms not only a random walk, but also other structural models.

In the remaining portion of this article, we will first review the literature. Section II analyzes methodology and structural models. Section III portrays the data and list of variables. Section IV analyzes the estimated models, and finally, Section $\mathrm{V}$ provides a conclusion.

\section{LITERATURE REVIEW}

There appears to be a consensus among researchers in existing exchange rate literature that the standard models which relate exchange rates to monetary variables, prices, interest rates, net foreign assets, etc., are off the mark. Sarno (2003) states that although the theory of exchange rate determination has produced a number of plausible models, empirical work on exchange rates still has not produced models that are statistically satisfactory. In particular, although empirical exchange rate models occasionally generate apparently satisfactory explanatory power in-sample, they generally fare poorly in out-of-sample forecasting tests in the sense that they fail to 
outperform a random walk. Richard A. Meese and Kenneth Rogoff (1983), as well as many subsequent economists, have found that a random walk predicts exchange rates better than structural models in the short run.

Frankel and Rose (1994) find that there is a bit of explanatory power to monetary models, such as the Dornbusch "overshooting" theory, in the form of reaction to news and in forecasts at long run horizons. Nevertheless, at short horizons, a driftless random walk characterizes exchange rates better than the standard models which are based on observable macroeconomic fundamentals.

Rogoff (1999) argues that despite longer datasets on modern floating exchange rates and the application of more sophisticated econometric techniques, researchers have continued to find it very frustrating to firmly demonstrate any systematic relationship between exchange rates and macroeconomic fundamentals, at least for the cross rates between the dollar, euro, and yen. He argues that it is true that researchers have occasionally found subsamples in which certain models seem to perform noticeably better than the random walk model, but as a rule, these results wilt under sustained out-of-sample tests.

Mark and Sul (1999) have studied the long-run relationship between nominal exchange rates and monetary fundamentals in a quarterly panel of 19 countries that extends from 1973.1 to 1997.1. Their results support the existence of cointegration among exchange rates and economic fundamentals. They also find supportive evidence that monetary fundamentals are able to forecast future exchange rate returns. Their panel regression estimates confirm that this forecasting power is significant.

Groen (2000) implements pooled time series estimation on a forward-looking monetary model, resulting in parameter estimates which are in compliance with the underlying theory. Based on a panel version of the Engel and Granger two-step procedure, they find that the residuals of the panel-based estimated monetary model are stationary, indicating that there is a cointegration between the exchange rate and the macroeconomic fundamentals of monetary models.

Cheung, Chinn and Pascual (2003) add other elements to the 1970s traditional specifications, such as the correlation between the external net asset and the differential of relative productivity in the tradable goods sector between countries (Balassa-Samuelson effect) for the determination of the exchange rate. They conclude that it is very difficult to find empirical estimations of structural models that may consistently outperform a random walk, applying the mean squared error (MSE) as the basis of comparison. However, they find that structural models provide better forecasts than those provided by a random walk.

Clarida et al. (2003) find evidence that the term structure of forward premia contains valuable information for forecasting future spot exchange rates and exchange rate dynamics display nonlinearities. Their paper proposes a term-structure forecasting model of exchange rates based on regime-switching vector equilibrium correction model, which significantly outperforms a random walk for four major exchange rates across a range of horizons.

Cheung et al. (2003) argue that previous assessments of the forecasting performance of exchange rate models have focused upon a narrow set of paradigms that were developed in the 1970s. In their paper, they reassess exchange rate predictability power by using a wider set of models than have been proposed in the last decade. These models include interest rate parity, productivity-based models, and a composite specification that incorporates the real interest differential, portfolio balance, and net foreign asset channels. The performance of these models is compared according to their out-of-sample predictability. The models are estimated in vector error correction and first-difference specifications. They examine model performance at various forecast horizons by using differing metrics (MSE), and show that structural models outperform a random walk.

Engel, Mark and West (2007) argue that standard models of exchange rates that are based on macroeconomic variables such as prices, interest rates, output, etc., are thought by many researchers to have failed empirically. However, they present evidence to the contrary. First, they emphasize that "beating a random walk" in forecasting is too strong a criterion for accepting an exchange rate model. They propose a number of alternative ways to evaluate models. They examine in-sample fits but emphasize the importance of the monetary policy rule and its effects on expectations in determining exchange rates. Next they present evidence that exchange rates incorporate 
news about future macroeconomic fundamentals, as the models imply. They demonstrate that the models might well be able to account for observed exchange-rate volatility. Finally, they show that out-of-sample forecasting power of models can be increased by focusing on panel estimation and long-horizon forecasts.

Moura and Lima (2007) use the generalized method of moments (GMM) for different specifications which employ Brazilian economic data from March 1999 to December 2005. They calculate the ratio between the MSE of each specification and that of a random walk. For short-run forecasting of one and three months ahead, the asset model is the only one that outperforms a driftless random walk at a forecast horizon of three months. For long-run forecasting horizons of six and twelve months ahead, the economic models outperform the forecasts obtained by a random walk in $37.5 \%$ of the flexible price monetary model, $56 \%$ of the sticky price monetary model, $50 \%$ of the market model and $100 \%$ of the asset model. The portfolio balance model, however, is always outperformed by a driftless random walk.

Lewis' (2007) empirical study demonstrates that changes in productivity affect the real euro-dollar exchange rate. He considers the two-sector new open macro model in Benigno and Thoenissen. The model predictions are used in the form of sign restrictions to identify productivity shocks in a structural vector autoregression (VAR) model. He estimates economy-wide and traded sector productivity shocks, controlling for demand and nominal factors. The results suggest that productivity shocks are much less important in explaining the variation in the euro-dollar exchange rates than are demand and nominal shocks. In particular, productivity can explain part of the appreciation of the dollar in the late 1990s only to the extent that it created a boost to aggregate demand in the U.S. Indeed, he finds an insignificant contribution of the Balassa-Samuelson effect.

Chinn and Frankel (2008) assert that the euro has risen as a credible, eventual competitor to the dollar as the leading international currency, much as the dollar rose to challenge the pound seventy years ago. They use econometrically-estimated determinants of the shares of major currencies in the reserve holdings of the world's central banks. Significant factors include the size of the home country, the rate of return, and liquidity in the relevant home financial center (as measured by the turnover in its foreign exchange market). There is a tipping phenomenon, but changes are felt only with a long lag. Their estimates correctly predicted an out-of-sample narrowed gap between the dollar and euro from 1999 to 2007. They assume that the dollar will continue to depreciate in the future at the trend rate that it has shown on average over the last twenty years. They conclude that the euro may surpass the dollar as the leading international reserve currency as early as 2015 .

Lam et al. (2008) find supportive evidence for the superiority of exchange rate models at long-term horizons. Their study compares the forecasting performance of the PPP model, the uncovered interest rate parity model, the sticky price monetary model, and the Bayesian model, averaging technique, and a combined forecast of all above models with a benchmark provided by the random walk model. Their empirical results suggest that the combined forecast outperforms the benchmark and generally yields better results than relying on a single model.

\section{METHODOLOGY}

We test the hypothesis that the euro will surpass the dollar by the end of 2009 as a result of Federal Reserve's policy to lower the FFR. What are the main determinants of the euro-dollar conversion rate? To put differently, which model best describes the predictability of the euro-dollar parity rate?

Consistent with Cheung, Chinn and Pauscal (2003), this study compares six empirical models versus a random walk: (i) the flexible price monetary model; (ii) the sticky price monetary model; (iii) the portfolio balance model; (iv) the Balassa-Samuelson model; (v) the interest rate parity model; and, finally, (vi) a composite specification, incorporating a number of channels which are identified in theoretical models. Needless to say, a driftless random walk is our benchmark.

We compare in- and out-of-sample predictability forecasts for the aforementioned models to examine which model best describes the euro-dollar relationship. 


\section{Flexible Price Monetary Model (FPMM)}

The Flexible Price Monetary Model was extremely applicable throughout the 1970s, when floating exchange rates were adopted by the main industrialized economies after the emergence of the Bretton Woods in 1973. The FPMM assumes that, in each country, the equalization of currency supply and demand determines the price level. As Moura and Lima (2007) show in their paper, the FPMM could be presented by:

$$
S_{t}=\beta_{0}+\beta_{1}\left(m-m_{t}^{*}\right)+\beta_{2}\left(y-y^{*}\right)+\beta_{3}\left(i-i^{*}\right)+\mu_{t}
$$

Where $S_{t}$ is the exchange rate logarithm, $m t$ and $m t^{*}$ represent the money supply and $y t$ and $y t^{*}$ represent the industrial production logarithm in both countries and $i t$ and $i t^{*}$ the logarithm for the interest rates.

\section{Sticky Price Monetary Model (SPMM)}

Despite the fact that the FPMM was the dominant approach to determining the exchange rate in the early 1970s, its weak empirical results led to the conception of models that took over friction in the economy and induced another form of convergence for long-run market equilibrium. Dornbusch (1976) introduces the idea of sticky prices in the short run to the exchange models. In essence, the existence of the jumps in the exchange rate and the interest rate would make up for the stickiness in the prices of goods. The sticky price monetary model can be expressed as follows:

$$
S=\beta_{0}+\beta_{1} \hat{M}+\beta_{2} \hat{Y}+\beta_{3} \hat{i}+\beta_{4} \hat{\pi}+u
$$

Where $m$ is $\log$ of money supply, $y$ is $\log$ real GDP, $i$ and $\pi$ are the interest and inflation rate, and $u t$ is an error term.

\section{Portfolio Balance Model}

Both of the aforementioned monetary models, flexible and sticky prices, assume a perfect substitution between home and external assets and their effects on the exchange rate. However, the existence of home-bias (home agents' preference for home assets) and liquidity difference can affect the presumed equilibrium in the monetary models, which makes the home assets and the external assets imperfect substitutes. The portfolio balance model assesses how this flawed substitution between home and external assets can affect the exchange rate. Thus, the specification can be expressed as:

$$
S_{t}=\beta_{0}+\left(P_{1}-P_{1}^{*}\right)+\beta_{1} Z_{t}+\beta_{2} F C L_{t}+\beta_{3}\left(i_{t}-i_{t}^{*}\right)+\beta_{4} E M_{t}+\beta_{5} D X R_{t}
$$

Equation (4-1) represents the model that imposes PPP, while the specification that assumes price stickiness could be expressed as:

$$
S_{t}=\beta_{0}+\beta_{1} Z_{t}+\beta_{2} F C L_{t}+\beta_{3}\left(i_{t}-i_{t}^{*}\right)+\beta_{4} E M_{t}+\beta_{5} D X R_{t}+\beta_{7}\left(\pi-\pi^{*}\right)
$$

Where $z t$ is the logarithm of the productivity differential for the tradable goods sector, $F C L$ is the net foreign currency liabilities, and $D X R$ is the logarithm of the public sector dollar denominated net domestic liabilities.

\section{Balassa-Samuelson Model}

Next, we assess the Balassa-Samuelson model, where it places important emphasis on productivity differentials to explain movements in real and nominal exchange rates. Real versions of the model can be traced to De Gregorio and Wolf (1994), while nominal versions include Clements and Frankel (1980) and Chinn (1997). Such models drop the purchasing power parity assumption for broad price indices and allow the real exchange rate to 
depend upon the relative price of nontradables, itself a function of productivity $(z)$ differentials. A generic productivity differential exchange rate equation is given by:

$$
S=\beta_{0}+\beta_{1} \hat{M}+\beta_{2} \hat{Y}+\beta_{3} \hat{i}+\beta_{4} \hat{Z}+u
$$

Although equations (2) and (5) bear a superficial resemblance, the two expressions embody quite different economic and statistical implications. The central difference is that (2) assumes that the PPP holds in the long run, while the productivity-based model makes no such presumption. In fact, the nominal exchange rate can drift infinitely away from the PPP as the path is determined by productivity differentials.

\section{Uncovered Interest Rate Parity}

Another specification that we assessed included the uncovered interest rate parity condition:

$$
S_{t, k}=S_{t}+\hat{i}_{i, k}
$$

where $i_{t, k}$ is the interest rate of maturity $k$. It is similar to the relative purchasing power parity (1). The interest rate parity is included in the forecast comparison exercise mainly because it has recently gathered empirical support at long horizons (Alexius 2001 and Meredith and Chinn 1998), in contrast to the disappointing results at short horizons. MacDonald and Nagayasu (2000) have also demonstrated that long-run interest rates appear to predict exchange rate levels.

\section{Composite Model}

is:

The last model is a composite that incorporates a number of familiar relationships. A typical specification

$$
S=\beta_{0}+\beta_{1} P+\beta_{2} \omega+\beta_{3} r+\beta_{4} g d e b t+\beta_{5} t o t+\beta_{6} n f a+u
$$

Where $\omega$ is the relative price of nontradables, $r$ represents the real interest rate, gdebt refers to the government debt to GDP ratio, tot represents the terms of trade, and $n f a$ is the net foreign asset.

Although this particular specification closely resembles the behavioral equilibrium exchange rate (BEER) model that was developed by Clark and MacDonald (1999), it also resembles Stein's model (1999) and Edward's (1989) real equilibrium exchange rate model, as well as a number of other approaches. Consequently, we will henceforth refer to this specification as the "composite" model. Again, relative to (1), the composite model incorporates the Balassa-Samuelson effect (via $\omega)$, the overshooting effect $(r)$, and the portfolio balance effect (gdebt, and $n f a$ ).

\section{DATA}

We use monthly data for macroeconomic, monetary and exchange rate variables from 2001-1 through 2008-5. The monetary and real data for the U.S. economy are retrieved from the Federal Reserve Bank of St. Louis, except for terms of trade and trade deficit, which is retrieved from U.S. Census Bureau and the productivity data from U.S. Bureau of Labor Statistics. The data for the EU are retrieved from European Central Bank Web site, except for the money supply, which has been retrieved from the Organisation for Economic Co-operation and Development (OECD) Web site.

The list of variables that we use is summarized in Table 1. 
Table 1- List of Variables

\begin{tabular}{ll}
\hline Name of variable & Explanation \\
\hline Exch & Euro-dollar exchange rate \\
USGDP & U.S. Gross Domestic Product \\
EUGDP & EU Gross Domestic Product \\
USM2 & U.S. Money Supply \\
EUM2 & EU Money Supply \\
FFR & Federal Fund Rate \\
Euribor1 & 1 month Euro interest rate \\
TOT & U.S. Terms of Trade \\
USPROPD & U.S. productivity \\
EUPROD & Euro Productivity \\
NASDAQ & U.S. NASDAQ Index \\
USNFA & U.S. Net Foreign Asset \\
EUNFA & EU Net Foreign Asset \\
USFDEBT & U.S. Foreign Debt \\
EUFDEBT & EU Foreign Debt \\
USCPI & U.S. CPI Index \\
EUCPI & EU CPI Index \\
D2 & Dummy variable from 2005:1 for the beginning of recession \\
\hline
\end{tabular}

\section{ESTIMATED RESULTS}

Table 2 presents the GMM estimated results for different structural models in comparison to a random walk. In the monetary model, the relative GDP, relative money supply, and relative interest rates are significant at a 99\% confidence level. In the sticky price monetary model, the relative GDP, money supply, and the relative CPI are each significant and of the expected sign. The portfolio balance model, with the inclusion of relative net foreign assets, fails to perform better than the sticky price monetary model, since both the relative interest rate and relative net foreign assets are insignificant.

The Balassa-Samuelson model indicates that not only are the relative GDP, money supply, and relative prices significant and of the expected sign, but the relative productivity also has a meaningful contribution to the parity of the euro-dollar. The estimated results for the interest rate parity model suggest that the interest rate differential can explain more than $98 \%$ of changes in the euro-dollar movements. It is worth mentioning that one standard deviation in the relative interest rate leads to a $1 \%$ appreciation of the euro against the dollar. The composite model, with the inclusion of relative net foreign asset, net foreign debt, terms of trade, and industrial Nasdaq, suggest that all variables except relative foreign debt are significant at a 99\% confidence level. Indeed, as the results suggest, all of the structural models can explain the exchange rate movements better than a random walk. The random walk model only explains $11 \%$ of the euro-dollar movements during the observation period.

To determine which model best describes the exchange rate movements; we apply different criteria, including the root mean squared error (RSME), the mean absolute error (MAE), the Theil coefficient, bias proportion and variance proportion. As shown in Table 3, the interest rate parity model outperforms all other structural models as well as the random walk. Indeed, as suggested by Frankel, the interest rate differential is the main factor that contributes to the exchange rate movements. Put differently, the European Central Bank and the Federal Reserve are the most important contributors to euro-dollar parity.

More importantly, the random walk model is data oriented, atheoretical, and unable to predict the exchange rate movements. The criteria shown in the following table suggests that structural models predict the exchange rate better than a random walk. 
Table 2- In-Sample Estimated Results for Different Models:

\begin{tabular}{|c|c|c|c|c|c|c|c|}
\hline Variable & $\begin{array}{c}\text { Random } \\
\text { Walk } \\
\text { Model }\end{array}$ & $\begin{array}{c}\text { Monetary } \\
\text { Model }\end{array}$ & $\begin{array}{c}\text { Sticky } \\
\text { Price } \\
\text { Monetary } \\
\text { Model } \\
\end{array}$ & $\begin{array}{c}\text { Portfolio } \\
\text { Balance } \\
\text { Model }\end{array}$ & $\begin{array}{c}\text { Balassa- } \\
\text { Samuelson } \\
\text { Model }\end{array}$ & $\begin{array}{c}\text { Interest } \\
\text { Rate } \\
\text { Parity } \\
\text { Model } \\
\end{array}$ & $\begin{array}{c}\text { Composite } \\
\text { Model }\end{array}$ \\
\hline Constant & $\begin{array}{c}0.0002 \\
(1.15)\end{array}$ & $\begin{array}{c}4.03 \\
(2.00)\end{array}$ & $\begin{array}{c}1.18 \\
(0.71)\end{array}$ & $\begin{array}{c}1.43 \\
(0.80)\end{array}$ & $\begin{array}{c}-3.96 \\
(-2.14)\end{array}$ & $\begin{array}{c}-0.11 \\
(-3.44)\end{array}$ & $\begin{array}{l}-71.08 \\
(-3.63) \\
\end{array}$ \\
\hline Exch $(-1)$ & $\begin{array}{c}0.34 \\
(3.54) \\
\end{array}$ & $\begin{array}{c}0.83 \\
(13.3) \\
\end{array}$ & $\begin{array}{c}0.83 \\
(14.6) \\
\end{array}$ & $\begin{array}{c}0.83 \\
(14.67) \\
\end{array}$ & $\begin{array}{c}0.99 \\
(16.66) \\
\end{array}$ & $\begin{array}{c}0.83 \\
(16.35) \\
\end{array}$ & $\begin{array}{c}0.76 \\
(14.21) \\
\end{array}$ \\
\hline USGDP/EUGDP & & $\begin{array}{c}0.46 \\
(2.40) \\
\end{array}$ & $\begin{array}{c}0.52 \\
(3.22) \\
\end{array}$ & $\begin{array}{c}0.57 \\
(3.17) \\
\end{array}$ & $\begin{array}{c}-0.51 \\
(-1.96) \\
\end{array}$ & & $\begin{array}{l}-5.77 \\
(2.85) \\
\end{array}$ \\
\hline USM2/EUM2 & & $\begin{array}{c}0.24 \\
(1.57) \\
\end{array}$ & $\begin{array}{c}-0.53 \\
(-1.84) \\
\end{array}$ & $\begin{array}{c}-0.55 \\
(-1.84) \\
\end{array}$ & & & $\begin{array}{c}-8.31 \\
(-5.02) \\
\end{array}$ \\
\hline FFR/Euribor1 & & $\begin{array}{l}-0.009 \\
(-2.10)\end{array}$ & $\begin{array}{l}0.002 \\
(0.55)\end{array}$ & $\begin{array}{l}0.004 \\
(0.80)\end{array}$ & & $\begin{array}{c}0.01 \\
(2.67)\end{array}$ & $\begin{array}{c}0.05 \\
(3.38)\end{array}$ \\
\hline USCPI/EUCPI & & & $\begin{array}{c}-3.33 \\
(-2.71)\end{array}$ & $\begin{array}{c}-3.52 \\
(-2.77)\end{array}$ & $\begin{array}{c}2.00 \\
(2.44)\end{array}$ & & \\
\hline TOT & & & & & & & $\begin{array}{c}-1.46 \\
(-2.84)\end{array}$ \\
\hline USPROD/EUPROD & & & & & $\begin{array}{c}0.07 \\
(3.04)\end{array}$ & & \\
\hline USFDEBT/EUFDEBT & & & & & & & $\begin{array}{c}0.02 \\
(1.31)\end{array}$ \\
\hline USNFA/EUNFA & & & & $\begin{array}{l}-0.006 \\
(-0.78) \\
\end{array}$ & & & $\begin{array}{c}-0.06 \\
(-1.54) \\
\end{array}$ \\
\hline Nasdaq & & & & & & & $\begin{array}{c}-0.97 \\
(-2.24) \\
\end{array}$ \\
\hline D2 & & & & & $\begin{array}{c}-0.02 \\
(-2.68)\end{array}$ & $\begin{array}{c}-0.04 \\
(-3.57)\end{array}$ & \\
\hline Trend & & & & & & $\begin{array}{l}0.001 \\
(3.78)\end{array}$ & \\
\hline R-Squared & 0.11 & 0.98 & 0.98 & 0.98 & 0.97 & 0.98 & 0.55 \\
\hline J Statistic* & & $2.88 \mathrm{E}-19$ & $4.72 \mathrm{E}-18$ & $9.88 \mathrm{E}-18$ & $6.73 \mathrm{E} 00$ & $1.51 \mathrm{E}-24$ & 2.40 \\
\hline
\end{tabular}

* H0: the over identification of instruments is satisfied

Table 3- Deviation Criteria for Different Models

\begin{tabular}{|l|c|c|c|c|c|}
\hline \multicolumn{1}{|c|}{ Model } & RMSE & MAE & Theil Coefficient & Bias proportion & Variance proportion \\
\hline Monetary Model & 0.029 & 0.022 & $\mathbf{0 . 0 1 1}$ & 0.0003 & 0.016 \\
\hline Sticky Price Model & 0.032 & 0.024 & $\mathbf{0 . 0 1 1}$ & 0.0025 & 0.079 \\
\hline Portfolio Model & $\mathbf{0 . 0 2 8}$ & 0.022 & $\mathbf{0 . 0 1 1}$ & 0.0002 & 0.009 \\
\hline Balassa-Samuelson Model & 0.038 & 0.026 & 0.014 & 0.0794 & 0.060 \\
\hline Interest Rate Parity & $\mathbf{0 . 0 3 0}$ & $\mathbf{0 . 0 2 0}$ & $\mathbf{0 . 0 1 1}$ & $\mathbf{0 . 0 0 0 1}$ & $\mathbf{0 . 0 0 3}$ \\
\hline Composite Model & 0.079 & 0.063 & 0.029 & 0.0036 & 0.021 \\
\hline Random Walk Model & $\mathbf{0 . 0 3 0}$ & $\mathbf{0 . 0 2 2}$ & $\mathbf{0 . 0 1 1}$ & $\mathbf{0 . 0 1 3 4}$ & $\mathbf{0 . 0 0 6}$ \\
\hline
\end{tabular}

Based on the estimated results, we applied the out-of-sample forecasts for different models at horizons of one, three, six, and twelve months. The results presented in Table 4 suggest that the euro-dollar parity rate will move in the range of 1.34 to 1.39 in the first month, 1.34 to 1.39 three months ahead, 1.34 to 1.42 six months ahead, and 1.34 to 1.51 twelve months ahead. 
Table 4- Out-of-Sample forecasts

\begin{tabular}{|l|c|c|c|c|}
\hline \multicolumn{1}{|c|}{ Model } & 1 Month & 3 Month & 6 Months & 12 Months \\
\hline Monetary Model & 1.37 & 1.39 & 1.42 & 1.46 \\
\hline Sticky Price Model & 1.37 & 1.38 & 1.41 & 1.47 \\
\hline Portfolio Model & 1.36 & 1.38 & 1.41 & 1.47 \\
\hline $\begin{array}{l}\text { Balassa-Samuelson } \\
\text { Model }\end{array}$ & 1.36 & 1.38 & 1.41 & 1.47 \\
\hline Interest Rate Parity & $\mathbf{1 . 3 4}$ & $\mathbf{1 . 3 4}$ & $\mathbf{1 . 3 4}$ & $\mathbf{1 . 3 5}$ \\
\hline Composite Model & 1.39 & 1.42 & 1.42 & 1.51 \\
\hline Random Walk Model & $\mathbf{1 . 3 7}$ & $\mathbf{1 . 3 5}$ & $\mathbf{1 . 3 5}$ & $\mathbf{1 . 3 4}$ \\
\hline
\end{tabular}

\section{CONCLUSION}

Using generalized method of moments (GMM), we estimate that different structural models are capable of predicting the performance of the euro-dollar exchange rate versus a random walk. The specifications herein the estimated results that we generated are consistent with those forecasted by the theoretical models, primarily the inclusion of monetary variables.

As a whole, the results suggest that monetary variables, which include the relative money supply, the interest rate differential, and relative prices, as well as the relative productivity, the terms of trade, relative net foreign assets and industrial Nasdaq, each play a crucial role in explaining the euro-dollar conversion rate.

As expected, the relative interest rate is significant in the monetary model, interest rate parity and the composite model. Indeed, with a standard deviation in FFR, the euro depreciates by $0.01 \%$. Put differently, the eurodollar conversion rate is statistically and significantly affected by the relative interest rate, which underscores the importance of the central banks' roles in deriving the exchange rate.

Based on RMSE, MAE, the Theil coefficient, bias and variance proportion, the interest rate parity model not only significantly outperforms other structural models, but also a random walk.

\section{AUTHOR INFORMATION}

Hamid Shahrestani, a native of Tehran, Iran, is Professor of Economics at Ohio University-Chillicothe. He received his B.A. in Economics from Concordia University in Canada, M.A. and Ph.D. in Economics from Western Michigan University and University of Cincinnati, respectively. In the past 30 years, he has been an active consultant in the private sector as well as a teacher and academic researcher. He can be reached by email: Shahrest@ohio.edu

Nahid Kalbasi Anaraki is an Assistant Professor of Economics at Islamic Azad University, Science and Research Branch in Tehran, Iran. She holds a Ph.D. in Economics from George Mason University in Virginia. Dr. Kalbasi is also an economic consultant for various manufacturing companies in Tehran. Her fields of interest are in International Economics and Monetary Theory.

Dr Farhad Ghaffari is an Assistant Professor at Islamic Azad University, Science and Research Branch, in Tehran. $\mathrm{He}$ has been teaching Macroeconomics, Econometrics, and Statistics at master level for more than 4 years. His majors are International Economics and Econometrics and his fields of interest are Financial Econometrics, Structural Macroeconomics modelling and Vector Auto-regression models.

\section{REFERENCES}

1. Alquist, Ron, and Menzie David Chinn. "Productivity and the Euro-dollar Exchange Rate Puzzle." National Bureau of Economic Research, Cambridge, MA, Working paper 8824, 2002.

2. Bangake, C. "Exchange Rate Volatility and Optimum Currency Area: Evidence from Africa." Department of Economics, University of Orleans, France, 2008. 
3. Blanchard, O., F. Giavazzi, and F. Sa. "The U.S. Current Account and the Dollar." National Bureau of Economic Research, Cambridge, MA, Working paper 11137, 2005.

4. Bordo, Michael. “A Long-term Perspective on the Euro.” National Bureau of Economic Research, Cambridge, MA, Working paper 13815, 2008.

5. Cheung, Y. W., M. Chinn, and A.G. Pascual. "Exchange Rate Models of the Nineties: Are Any Fit to Survive?" University of California and IMF, 2003.

6. Chinn, M. and Jeffrey Frankel. "The Euro May Over the Next 15 Years Surpass the Dollar as leading International Currency.” National Bureau of Economic Research, Cambridge, MA, Working paper 13909, 2008.

7. Clarida, R. H., L. Sarno, M. Taylor, and G. Valente. "The Out of Sample Success of Term Structure Models as Exchange Rate Predictors: A Step Beyond.” Journal of International Economics 60 (2003): 6183.

8. Dooley, M. P., D. Landau, and P. Garber. "Interest Rates, Exchange Rates and International Adjustment." National Bureau of Economic Research, Cambridge, MA, Working paper 11771, 2005.

9. $\quad$ Engel, C., N. C. Mark, and K. D. West. "Exchange Rate Models Are not as Bad as You Think." National Bureau of Economic Research, Cambridge, MA, Working paper 13318, 2007.

10. Faust, J., J. H. Rogers, E. Swanson, and J. H. Wright. "Identifying the Effects of Monetary Policy Shocks on Exchange Rates Using High Frequency Data." National Bureau of Economic Research, Cambridge, MA, Working paper 9660, 2003.

11. Feldstein, M. "Why Is the Dollar So High.?” National Bureau of Economic Research, Cambridge, MA, Working paper 13114, 2007.

12. Frankel, J. A. and A. K. Rose. "A Survey of Empirical Research on Nominal Exchange Rates.” National Bureau of Economic Research, Cambridge, MA, Working Paper W4865, 1994.

13. Goldberg, L. and C. Tille. "The International Role of the Dollar and Trade Balance Adjustment." National Bureau of Economic Research, Cambridge, MA, Working paper 12495, 2006.

14. Groen, J. J. "The Monetary Exchange Rate Model as a Long-run Phenomenon.” Tinbergen Institute, Erasmus, University of Rotterdam, Netherlands, 2000.

15. Kalbasi, Anaraki N. "Meese and Rogoff's Puzzle Revisited." Journal of International Review of Business Research Papers 3.2 (2007):

16. Lam, L., L. Fung, and I. W. Yu. "Comparing Forecast Performance of Exchange Rate Models.” Hong Kong Monetary Authority, Research Department, Working paper 08/2008.

17. Lewis, Vivien. "Productivity and the Real Euro-Dollar Exchange Rate." Review of World Economics 127(2) (2007): 324-348.

18. Lim, H. S. and M. Ogaki. "A Theory of Exchange Rates and the Term Structure of Interest Rates." Department of Economics, Ohio State University, 2003.

19. Mark, N.C. and D. Sul. "Nominal Exchange Rates and Monetary Fundamentals: Evidence from a Small Post-Breton Woods Panel." Department of Economics, Ohio State University, 1999.

20. Meese, R. A. and K. Rogoff. "Empirical Exchange Rate Models of the Seventies, Do They Fit Out of Sample?" Journal of International Economics 14 (1983): 3-24.

21. Molodtsova, T., and D.H. Papell. "Out-of-Sample Exchange Rate Predictability with Taylor Rule Fundamentals." Department of Economics, University of Houston, 2008.

22. Moura, M. L., and A. R. S. Lima. "Empirical Exchange Rate Models Fit: The Case of Brazil." Ibmec Sao Paulo Business School, Brazil. 2007.

23. Rogoff, K. "Monetary Models of Dollar/Yen/Euro Nominal Exchange Rates: Dead or Undead?" The Economic Journal 109.459 (1999): 655-659.

24. Rogoff, K. "The Failure of Empirical Exchange Rate Models: No Longer New But Still True." Economic Policy Web Essay, 2001.

25. Rogoff, K. "New Perspectives on International Debt and Exchange Rates." National Bureau of Economic Research, Cambridge, MA, 2004.

26. Sarno, L. "Nonlinear Exchange Rate Models: A Selective Overview.” International Monetary Fund, Working Paper 111, 2003.

27. Tille, C., S. Nicolas, and O. Gorbachev. “To What Extent Does Productivity Drive the Dollar?” Federal Reserve Bank of New York 7.8 (2001): 
NOTES 